Keiko MITANI

UDK 821.163-3“"13/16“.09

University of Tokyo

$2-252: 811.163$

Tokyo

kmitani@mb1.suisui.ne.jp

Izvorni znanstveni članak

Primljen: 10. siječnja 2017.

Prihvaćen: 20. rujna 2017.

\title{
THE CROATIAN TRADITION OF THE STORY OF AKIR THE WISE IN SOUTH SLAVONIC RECENSIONS
}

This paper attempts to uncover the textual relationships between Croatian manuscripts of the Story of Akir the Wise and other South Slavonic copies of the same text. The Story of Akir the Wise, an apocryphal text originating in the ancient Middle East earlier than 500 B.C., was translated into Church Slavonic, probably in the 12th or the 13th century. The story was disseminated mostly among the Orthodox Slavs, but was also transmitted to the Catholic Slavs in Croatia. The South Slavonic copies, although outnumbered by the Russian ones, include the oldest extant manuscript preserved at the Savina Monastery in Montenegro. The question of the Slavonic archetype of the Story is still open because of the absence of a Greek recension. In Croatia, three copies have been preserved in Glagolitic, Cyrillic, and Latin scripts. This paper treats the South Slavonic copies of the Story, composed from the 14th to the 17th century inside and outside Croatia, and points out some textual features connecting the Croatian copies with other Cyrillic copies composed in Serbia and Bulgaria. Based on text-critical analysis, it is argued that the Croatian copies have a common source, which is a descendent of another older source that appeared in the Slavia Orthodoxa; some Serbian and Bulgarian copies also derived from that source. The paper also argues that the scribes of the Story not only copied their source texts but furthermore intentionally engaged in editing their texts in accordance with the language practices and social environment within which they worked.

Key words: The Story of Akir the Wise, Slavonic apocrypha, Medieval Croatian writings, Croatian Glagolitic literature, Slavia Latina and Slavia Orthodoxa 


\section{INTRODUCTION}

The Story of Akir the Wise ${ }^{1}$ (hereafter SAW), originating in ancient Mesopotamia, was transmitted to the neighboring regions: translations are found in Syriac, Armenian, Egyptian, Georgian, and Rumanian (CONYBEARE; HARRIS; LEWIS 1898; COWLEY 1923; WEIGL 2010). The fact that the cult of the Assyrian vizier Akir (Ahikar) entered the Jewish world can be proved by the Book of Tobit, in which Akir, namely Achiacharus, appears as Tobit's nephew (Tobit 1.22; NAU 1909: 11; LITTMAN 2008; LINDENBERGER 2008). Some versions of The Story of One Thousand and One Nights contain SAW as well (MARZOLPH; VAN LEEUWEN; WASSOUF 2004: 219-220). SAW was translated into Church Slavonic, probably in the 12-13th c., although it is unknown where this took place, and disseminated in Russia, Bulgaria, and Serbia, as well as in Croatia.

Despite the broad circulation of SAW in the eastern part of the medieval Mediterranean and the area of the Near East, a Greek text has not been found. Although, the resemblance of some episodes narrated in SAW to the biography of Aesop strongly suggests that the SAW was known to the ByzantineGreek world and was somehow interwoven with the story of Aesop. ${ }^{2}$ The lack of a Greek text raises a serious question regarding the source of the Slavonic tradition of SAW.

SAW awoke scholarly interest among Slavic researchers of the 19th century, and since then it has been much discussed, particularly regarding the source of the Slavonic recensions of SAW. Less work has been done, in contrast, investigating the textual relationships among the South Slavonic recensions, particularly the connections of copies appearing in Slavia Orthodoxa and those composed in Slavia Latina. ${ }^{3}$ These are the aspects that this paper aims to uncover.

This paper is structured as follows: firstly, the storyline, as well as recensions and copies of Slavonic SAW are surveyed; secondly, the textual features

1 Priča o premudrom Akiru in Croatia: ŠTEFANIĆ 1969; BADURINA STIPČEVIĆ 2013: 251260. Otherwise, also Слово Акира премудрог in Serbia (STANKOVIĆ 1980; JOVANOVIĆ 2012); Повестта за Акир Премудри in Bulgarian (IVANOV 1935; KUZIDOVA 2010), and Повесть об Акире Премудром іn Russia (TVOROGOV 2004).

2 The Biography of Aesop was edited by Maximus Planudes, c.1260-c.1305, and translated into modern European languages. On the Slavonic translation of the life of Aesop, see, for example: SYRKU 1884: 78-98; IVANOV 1935: 245-249. On the relationship of SAW and the biography of Aesop, PYPIN 1855; GRIGOR'EV 1913: 315-354.

3 A recent study by Kuzidova (KUZIDOVA 2012) examined the South Slavonic copies in detail, but the Croatian copies and Rs53, a Serbian copy, are excluded; Badurina Stipčević treats the three Croatian copies but does not include other South Slavonic copies outside Croatia. 
of three Croatian copies are examined; thirdly, the relatedness of the Croatian copies and other early Slavonic copies is explored, and finally, the pattern of transmission and the way in which the text was rewritten in the South Slavic region are proposed.

\section{STORY AND RECENSIONS}

\subsection{Story}

The composite feature of SAW was already visible in its oldest evidence written in Ancient Aramaic: the text was made up of a narrative of Ahikar told in the first person singular style and a series of instructions directed from father to son. The later recensions composed in different languages show more enlarged structures with additional episodes and sayings; nevertheless, the core structure of the ancient papyri text was reflected mostly unchanged, as witnessed in Syriac and Armenian as well as in Slavonic versions.

As a result of textual enlargement, the later versions of SAW had a quadripartite structure. The first part functions as an introduction in which the ancient narrative of the Aramaic text is reproduced: in spite of all his wealth and power Akir laments his misfortune of not having his own offspring, and in obedience to a divine revelation decides to adopt his nephew, Anadan. Akir's fostering of Anadan thus begins. The next part consists of a series of sayings addressed to Anadan, each sentence starting with the phrase »My son (son's name)«. This part, enriched with various quotations from other books of wisdom, such as the Book of Proverbs and Psalms, might be treated independently as pertaining to the »wisdom literature«. After this rather lengthy part of instruction, the narrative returns to the main story that unfolds around the relationship between Akir and Anadan. The latter, having been educated and nominated as Akir's successor, shortly discloses his evil nature and plots against Akir, which changes Akir's fate. Many episodes of Eurasian folkloric origin, such as the foreign ruler's threat, riddles and a duel of wits, and the hero's final triumph, are interwoven in this part. ${ }^{4}$ Finally, in the last part Akir, having surmounted his ordeal, comes back to power and punishes Anadan with death.

4 See e.g. RADENKOVIĆ 2009: 107-114. The episode of »building a castle between the earth and the sky« is also found in the biography of Aesop. »To make a rope from sand (из песку веревки вьет)« = 'perform what looks to be impossible' is a proverb broadly known in various nations in Europe: MICHEL'SON 1912: 570. On the literary subject of SAW, see e.g. IONOVA 1978; GLADKOVA 2008: 614. 


\subsection{Recensions}

The number of Slavonic copies of SAW is estimated at around 60, among which Russian copies count for nearly 50, while South Slavonic copies number around 10 (BELOBROVA; TVOROGOV 1970: 142-194, in particu$\operatorname{lar} 163-180) .^{5}$

\subsubsection{Russian recensions}

Russian study of SAW was started by 19th century scholars such as Polevoj (POLEVOJ 1825; 1842) and Pypin (PYPIN 1855), and was continued by the 20th century scholars Grigor'ev (GRIGOR'EV 1913), Durnovo (DURNOVO 1915), and Perets (PERETS 1916). Their main interests were the source of the Slavonic translation of SAW and the question of whether the oldest translation was composed in Kievan Rus or somewhere in the South Slavic region. Based on a comparative analysis of the older Slavonic copies with Syriac and Armenian texts, Grigor'ev concluded that the first Slavonic SAW appeared as a translation from the Syriac version. A recent study by B. Lourié supports the Syriac source too, but from a different mode of analysis (LOURIÉ 2013). However, the hypothesis of Greek origin, proposed by Jagić (JAGIĆ 1868) and DURNOVO (1915; 1931), has not been completely dismissed until now.

A Russian copy contained in the Musin-Pushkin miscellany probably dates from the late 15th century and is regarded as not only one of the oldest in the Russian tradition of SAW, but also the closest to the Slavonic protograph. ${ }^{6}$ Unfortunately, the miscellany was destroyed in 1812 and only a brief description of it by N. Karamzin was left as the sole evidence of the existence of this copy (KARAMZIN 1818: 165). ${ }^{7}$

According to the Russian scholarly tradition based upon Durnovo (DURNOVO 1915), Russian copies are divided into several recensions, at least two, among which those older and closer to the Armenian and Syriac versions are

5 According to a traditional Russian view, there are 47 Russian copies of SAW. However, the existence of another fragmentary copy or more modified copies can be presumed, given the popularity of the story in Russia, in particular among the Old Believers; cf. PIOTROVSKAJA 1976; 1978.

${ }^{6}$ For Musin-Pushkin's miscellany, see for example BOBROV 2014.

7 Here the author writes: »вписаны еще двъ повъсти: Синагрипъ, Царь Адоровъ и дъяніе прежнихъ временъ храбрыхъ человъкъ...« (two more stories were written: Sinagrip, King Adorov and The Deeds of Brave People in the Past...), and the very beginning of SAW was copied: »Въ то время азь Акыръ книгчій (книжникъ) бъ и речено ми есть отъ Бога: отъ тебе чадо не родится...« 
treated as the first. ${ }^{8}$ This recension is usually represented by a manuscript contained in OIDR 189, No.4. To the second (Durnovo's third Russian) recension younger copies belong, mostly appearing from the 17th century onward with more conspicuous rewritings as well as deletions of sayings. The younger recension was transmitted up to the 19th century among the Old Believers (DURNOVO 1915: 89-98; PERETS 1916; TVOROGOV 1969; PIOTROVSKAJA 1976; PIOTROVSKAJA 1978; VOLKOVA 2011).

\subsubsection{The South Slavonic recensions}

The South Slavonic copies of SAW were first made known to the world by V. Jagić. ${ }^{9}$ In his History of Literature of Croatian and Serbian People Jagić could only suggest the existence of South Slavonic variants of SAW (JAGIĆ 1867: 102), but in the work published the following year as an addition to the History, he presented a Cyrillic copy of Dalmatian-Bosnian provenance dated 1520, which was formerly possessed by I. Kukuljević. On this occasion, a Glagolitic copy contained in Petris Miscellany (1468) was also published in Cyrillic transliteration, albeit only as an apparatus to be compared to the Cyrillic one (JAGIĆ 1868: 137-148). ${ }^{10}$ The Cyrillic copy was later republished by M. Rešetar together with the entire miscellany containing it, namely HAZU ${ }^{11} I V$ a 24 , titled Libro od mnozieh razloga (REŠETAR 1926). As regards the Glagolitic copy, V. Stefanić published some extracts in Latin transliteration in an anthology of medieval Croatian literature (ŠTEFANIĆ 1969: 304-311), but a complete Latin transliteration was not published until Badurina Stipčević (2013). In Croatia, another copy of SAW, written in Latin script, was also composed (HERCIGONJA 2002: 11-54). We shall examine these Croatian copies in the sections below.

Jagić's contribution to uncovering the South Slavonic tradition of SAW was enhanced by E. Barsov (BARSOV 1886: 1-11), I. Grigor'ev (1913), and N. Durnovo (DURNOVO 1915: 37-44). Later, R. Stanković added his own contribution (STANKOVIĆ 1980).

\footnotetext{
${ }^{8}$ In DURNOVO (1915: 89-98) a »Serbian« copy, B828, is treated as »the second Serbian« recension. We count this recension separately; thus, Durnovo's »the third Russian« recension is treated here as the second.

${ }^{9}$ Another contribution of Jagić concerning the study of SAW is probably his translation of the Slavonic text into German, which provided Western readers with a good knowledge of the Slavonic tradition of SAW: JAGIĆ 1892.

${ }^{10}$ Petris miscellany is kept in the Croatian National and University Library in Zagreb, call number R4001. On Petris Miscellany, see BRATULIĆ; DAMJANOVIĆ 2005: 152. The description is given in ŠTEFANIĆ 1960: 355-397.

11 The abbreviation of Hrvatska akademija znanosti i umjetnosti / Croatian Academy of Sciences and Arts.
} 
In 1985, an apocryphal miscellany dated 1380 was discovered at the Savina Monastery in Montenegro by D. Bogdanović and A. Miltenova where a copy of SAW was found (BOGDANOVIĆ; MILTENOVA 1978). This discovery raised a fundamental question about the traditional Russian scholarly view that SAW was first translated in Kievan Rus and from there migrated to the Slavic South. The copy was published recently by I. Kuzidova (KUZIDOVA 2010). ${ }^{12}$

In what follows, we will first examine the linguistic and textual features of three Croatian copies and then compare them with other South Slavonic, as well as Russian, recensions in order to clarify their textual relationship. The following are the copies treated in this paper: ${ }^{13}$

B828 A Serbian copy, dated 16th c.; Serbian National Library, No. 828, lost in 1941 (DURNOVO 1915).

B53 A 16th century copy, Bosnia; Serbian National Library, Rs53, 46r-56r.

Ch A »Serbian« copy, dated 16th c.; Chertkov Library, No254 (BARSOV 1886).

$D \quad$ A Croatian copy written in Latin script by I. Derečkaj, in 1622-1623; National and University Library in Zagreb, R3495 (HERCIGONJA 2002).

$L \quad$ A Cyrillic copy dated 1520, in HAZU IV a 24: Libro od mnozieh razloga (REŠETAR 1926).

$P \quad$ A Glagolitic copy in Petris Miscellany dated 1468 (BADURINA STIPČEVIĆ 2015).

RI A copy of Russian provenance from the 16th c., OIDR 189 (TVOROGOV $\left.2004^{14}\right)$.

Sav29 A copy found in the miscellany of Savina Monastery, No. 29, dated from around 13-14th c. (KUZIDOVA 2010).

S309 A Bulgarian copy, dated the second half of the 16th c.; SS. Cyril and Methodius National Library, Sofia, NBKM309 (Beljakov's miscellany), $4 \mathrm{r}-26 \mathrm{v}$.

\footnotetext{
${ }^{12}$ For other South Slavonic copies of Bulgarian and Serbian provenance, KUZIDOVA 2012; also The Repertorium of Old Bulgarian Literature and Letters: http://repertorium.obdurodon. org/ (accessed August 20th 2017).

${ }^{13}$ The textual analysis of this paper is based on the published texts cited here except for $B 53$ and $S 309$, for which the original manuscripts Rs53 and NBKM309 were consulted. Quotations are presented as they appear in the source texts; sources of quotations are indicated by the pages if they are published, otherwise by folios. Underlines in the quotations are mine.

14 TVOROGOV 2004 is a critical edition based on OIDR 189.
} 


\section{THREE CROATIAN COPIES}

\subsection{Linguistic features of $P, L, D$}

As previous studies such as DURNOVO (1931) and BADURINA STIPČEVIĆ (2015) have shown, the Croatian copies of SAW are characterized first of all by their shortening of the text to different degrees. The longest of the three is $P$, but its length is no more than two-thirds that of $S 309$, which is still shorter than $R I$. $L$ shows a considerable deletion of part of the sayings, and the entire length of the text is almost half that of $S 309 . D$ is a further shortened version with a total of 6 pages (Cir. 55 letters per line, 22 lines on a page/folio).

The three Croatian manuscripts are characterized also by scribes' intentional replacing of words and phrases in the source text with the vernacular idioms that were more usual in the community to which each scribe belonged.

$P$ still preserves traits of Old Church Slavonic, but features of vernacular C̆akavian mixed with Kajkavian prevail (see HERCIGONJA 1983: 303-311). For example, ašte 'if' is used twice, whereas ako, the vernacular Croatian form, is used 34 times; the iže-type Old Slavonic relative pronoun occurs only once as $e \check{z} e$ in the neuter nominative form, while typical vernacular forms such as $k i$ and $k a$ are used elsewhere. Regarding the interrogative pronoun, the Čakavian form $\check{c} a$ is preferred with 18 examples against $k a j$, which is used only twice. ${ }^{15}$ The reflex of *ě is $i$ or $\hat{e}(\mathrm{~b}):{ }^{16}$ lipotu (ljepota $<*$ lěpъ 'beauty'); misto (mjesto < *město 'place'), miseca (mjesec < *měsęcь 'month'); pêsak (pijesak $<$ *pěsъkъ 'sand').

$L$ is written in a vernacular language with conspicuous Štokavian-Iekavian features; the interrogative pronouns are exclusively що (što) and тко (tko); typical Štokavian phonological changes are reflected orthographically, e.g. $*_{\mathrm{vs}}$ > sv-: сваки, свакои (< * vьsь- 'every'), *1> o: могао (the 1-participle masculine singular of moći $<*$ mogt'i 'can'), ocao (< osal <*osblъ 'donkey'). The reflex of *e is ie: лиепоту, миесеиy, пиеску, with the occasional appearance of $i$, ex., изио (the 1-participle masculine singular of izjesti $<*$ jьz-ěsti). Also the prefixal form pri-instead of pre- $(<*$ per- $)$ is evidenced: примудри $(<$ premudri 'sage,' cf. приемудрости).

$D$ uses što for the interrogative $(19 \times)$ against one example of $\check{c} a ; k a j$ is not used at all. Contrary to this seemingly typical Štokavian feature, other

\footnotetext{
${ }^{15}$ Only the uses of nominative forms are counted.

${ }^{16}$ E represents the Glagolitic jat (the Cyrillic b). Forms presented in parentheses are Standard Croatian and Proto-Slavic, in this order. Proto-Slavic forms are based on ESSJA 1974 if available, otherwise on KOPEČNÝ 1981: 198.
} 
Štokavian traits such as $\mathrm{jd}>\mathrm{dj}>\mathrm{d}$ and $-1>-\mathrm{o}$ are not witnessed: pojde, po$j t i$; hotil ( $P$ : hotêl, $L$ : хотио $<*$ xotěti), osal ( $P$ : osal, $L$ : ocao). The relative pronouns are $k i, k a$. The reflex of $*$ ě is $i$ : dite $(<*$ dětę), hlib $(<$ xlěbъ). Thus, despite the usage of $\check{s} t o, D$ is regarded as written not in Štokavian but in a vernacular language rather close to that of $P$, or, as Hercigonja characterized it, in a certain kind of dialectal hybrid used at the time of the composition of $D$ (HERCIGONJA 2002: 12-13).

\subsection{Textual relationship}

As previous studies have already pointed out (DURNOVO 1931; KUZIDOVA 2010; BADURINA STIPČEVIĆ 2015), various types of rewriting are observed in the Slavonic copies of SAW, which appear to make it difficult to reconstruct their textual relationships. Omission and addition of episodes are not rare and lexical replacement is witnessed elsewhere. In particular, the make-up of the second part looks quite unstable: some sayings are deleted while new ones are incorporated, expressions used in sayings often vary according even from copy to copy, and the orders of the sayings are seemingly unpredictable, albeit not totally arbitrary. All these features appear to hinder us in defining which particular copy belongs to which particular recension or group of recensions. Still, several common features are observable in certain groups of copies, and such features do help us to restore the textual relationship of the South Slavonic copies. It is this aspect that we will attempt to uncover in the following:

3.2.1. Three Croatian copies present different degrees of commonality but also divergence among themselves. The most noticeable is the closeness of $P$ and $D$, which was already pointed out by HERCIGONJA 2002 and laid out at length by BADURINA STIPČEVIĆ 2015. Instead of repeating their views, we will limit ourselves to drawing attention to the following passage in $P$, which mentions the episode of Samson and Delilah narrated in the Book of Judges to warn his son against an evil wife:

$P$ Sinu moi Anadane pomeni Adaletu Sam'sonovu ženu kako ostrigši Samsona i oslepi i prêda inoplemenikom vragom' i on' za žalost' obori grad' na se i pogubi priêteli i nepriêteli svoe [pp. 384-385]

'My son, remember Adaleta, Samson's wife, who cut his hair, blinded him, and sold him out to his enemies, and he, because of his despair, destroyed the town and killed not only his enemies but also his people.'

The same passage or a similar one is not evidenced in any other copies of any recensions, except for $D$ : 
$D$ Sinu moj spomeni se na Dallillu Samsonovu ženu ka istriže vlasi njemu, i proda ga neprijatelem ki ga oslipiše [p. 25]

'My son, remember Delilah, Samson's wife, who cut his hair and sold him out to his enemies who blinded him.'

The sentence in $D$ is shortened and the wording is not identical with $P$, but its connection to the passage in $P$ is indubitable. Instead of presenting further evidence, we decide henceforth to treat $P$ and $D$ as forming one group of the same recension and mark them $P / D$ when common features are relevant.

Note here, however, that the closeness of $D$ to $P$, as observed above, does not imply that $D$ is merely an abridgement of $P$. Derečkaj's attitude to copying is characterized not only by a reduction of the source text and change of wording but also by lexical replacement: the scribe often substitutes lexical elements, such as car/cesar in P with kralj ('king'), hlib with kruh ('bread'), rab with sluga ('servant'), and hram with hiža ('house'). These substitutions clearly indicate Derečkaj's intentional engagement of »translating « the language of the source text into the idiom more accustomed to himself and recipients of his edition of SAW.

3.2.2. Our observation further reveals that, despite the differences of scripts and language features, $P / D$ and $L$ have the following common features (I)-(IV):

(I) The lack of an episode. $P / D$ as well as $L$ lack an episode that should be narrated at the beginning of the third part, which otherwise unfolds from Anadan's nomination as a successor to Akir, through descriptions of Anadan's misdeeds and wickedness, to his rapid dismissal that triggered the treachery of the ill-disposed foster son against Akir. We need to add here, however, that the lack of this part indeed indicates the connection of these copies, yet this feature is shared with other copies composed outside Croatia as well. We will return to this point in Section 3 below.

(II) A quotation of a verse from the Bible. In $P / D$ and $L$ the second part starts as presented below:

$P$ I rêh' sinu moi Anadane prvo načelo prêmudrosti est' strah' g(ospod')n'. Po tom' budi skor slišati. . . [p. 389]

$L$ и риехь наипарво сину мои анадане парво ти почело приемудрости страхь гна бога потомь буди скоро слишати. . . [р. 48]

$D$ I Rekoh mu. Sinu moj Anadame, Pervi početak mudrosti jest strah gospodinov. Potom budi barz slišati, ... [p. 23]

'And I said. My son, Anadan, the very beginning of wisdom is the fear of the Lord. And then be always ready to be obedient ...' 
The underlined parts are noteworthy in that, for one thing, they surely point to one common source of quotation, which as far as we can currently judge may be either Psalms 110:10 or Proverbs 1:7, and moreover these are dissimilar to other copies, which usually start the same part with quite different phrases. Let us illustrate this with $R I$ and Sav29:

$R I$ и глаголахъ ему тако: Человъче, внимай глаголы моя, господину мой Анадане! Всякому наказанью яснъ буди во всъх днехъ жития твоего [р. 30]

'And I told him: listen to my words, my Anadan! Be aware of every instruction of mine in every day in your life'

Sav29 и рекохь ґмоу. прими Глли мою. Сйоу мою Анаิнане вса все (!) наказанию послоушамы мене [p. 499]

'And I told him: Accept what I say, my son, Anadan, be obedient to my instruction'

Though different in wording, the commonalty of both copies of teaching his son to be obedient to his father's instructions is evident. Moreover, the concordance of these with the corresponding part of the Syriac recension ${ }^{17}$ indicates that the quotations from the biblical text contained in the Croatian copies derive from a later incorporation.

(III) The metaphor of »a ship with a hole«. The second part of SAW usually includes quite a few instructions that refer to the evils of women. A typical one can be read as illustrated by $S 309$ and $R I$ below:

S309 Сн̈е добреише 亡ீ огницею или тресавицею болети, нежели сьзлою женою жити. [11v]

$R I$ Сыну, уне есть огнем больти, али // трясавичею, негли жити со злою женою [p. 34//36]

'Son, it is better to remain in fever heat than to live with a wicked wife.'

In this relation $P$ and $L$ reveal their close connection, as they contain mostly identical phrases with which, by means of the metaphor of a ship with a hole, the father warns against evil women. This type of instruction is not found in Russian or many South Slavic copies.

$P$ Zač' bolê se e va ut'li ladi voziti na gluboci vodi nego sa zlom ženom svêt' imêti. Ere ut'la ladê hoće ednu dušu pogubiti a zla žena mnog' žitak' podvratiti. [p. 392]

\footnotetext{
17 »Hear, O my son Nadan, and come to the understanding of me, and be mindful of my words, as the words of God « (CONYBEARE; HARRIS; LEWIS 1898: 60).
} 
$L$ иере ти се ие боле возити у-утли лади у-судбци ${ }^{18}$ води неголи имати свиеть са зломь женомь иере утла ладия иедну душу хоће погубити а-зла жена много жизниехь хоће расточити [р. 49]

'Since it is better to sail into the deep water on a ship with a hole than to live with an evil woman, because a ship with a hole would kill one soul, but an evil woman would destroy many lives.'

(IV) The date and the place in the forged letters of Anadan. The fatal date and the place written in Anadan's forged letters to plot against Akir are, in the Syriac recension, "August the 25 th $«$ and $»$ the field of Egypt $«{ }^{19}$ these are reflected in old Slavonic recensions. To illustrate this, we will look at $R I$ and $C h$ :

$R 1$ И готовъ буди и приди на поле Егупетьское мъсяца августа въ 25 день [p. 40]

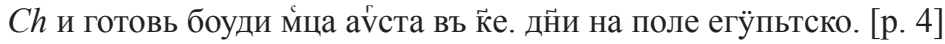

'and hold in readiness on the plane of Egypt, on August 25th'

In contrast, in $P / D$ and $L$ the month appears as »March«, while the day reads »6th« in $P / D$ and » 15 th» in $L$; also the field is changed to »Odor» from »Egypt«:

$P$ veli ti Akirı gotov' budi .e. dan' miseca marča na poli na Odorskom' [p. 393]

$L$ буди готовь петнаисте дни миесеца марча на-полу на-одорскомь [р. 50]

$D$ da budeš na šesti dan miseca marčja na pol[j]u na vdovskom $\quad$ [p. 37]

It is not known when and why the date »August 25th« was copied differently, in particular regarding the change from August to March, yet the deviation of the date from the 25 th (in old Cyrillic ..$\vec{k}$. $)$ to the forms written in the three Croatian copies may be explained as follows: first, the change of . occurred at some stage of transmission, supposedly by scribal error, and that .ं.

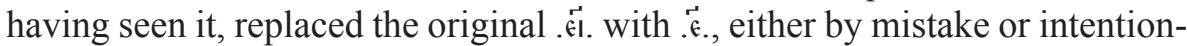
ally. This .'夭. was meanwhile transmitted, reproduced as »šest « in accordance with the numbering system of the Glagolitic script, resulting in Derečkaj's »šest «. The scribe of $L$ evidently looked at .. i. in his source text and spelled it with letters as »петнаисте«.

${ }_{18}$ Rešetar notes this as »probably a miscopy of $d u b c i \ll$.

${ }^{19}$ In the Syriac text the part in question reads: »come to meet me at Eagles's dale, which lieth to the south, on the 25th day of the month Ab. « (CONYBEARE; HARRIS; LEWIS 1898: 67). The month $A b$ in Syriac means August (SMITH 1903: 2). The same part of the Armenian version appears as: „)come to the plane of Eagles on the 25th day of the month Hrotitz, and $<\ldots>$ (ibid. 37). Hrotitz is according to the old Armenian calendar the last month of the year, namely, from July to August [BROSSET 1832: 531]. 
The observations so far allow us to state that $P / D$ and $L$ have a common source, forming one textual group of a particular South Slavonic recension. If further proof is needed, we may add another phrase commonly found in $P$ and $L$. In old Near Eastern recensions, such as Syriac and Armenian, we read a saying: »Son, a rich man's son hath eaten a serpent, and they say it is medicine for him. A poor man's son hath eaten it, and they say that he ate it out of hunger.« (CONYBEARE 1898: 26). This phrase is indeed included in most of Slavonic recensions, including $P$ and $L$, but in Croatian copies, there appears an additional clause of »My Son, Anadan, such is a life«:

$P$ Sinu moi Anadane bogata muža sin' biše zmiju izel'. i rêkoše emu ljudi likarieĉe radi vzel'. I uboga muža sin' biše zmiju izel' i rekoše ljudi gladajuće radi izel'. Sinu moi Anadane tako ti e u sem' svêtu. [p. 392]

$L$ Сину мои анадане богата оца синь биеше змию изио рекли би луди лиека ие циећь изио, сину мои Анадане убога мужа синь биеше змию изио и рекоше луди глада ю ие циећь и изио. сину мои Анадане такои-ти е у овомь свиету. [33v/p. 50]

3.2.3. It should be noted of course that although the existence of common source for $P / D$ and $L$ is indubitable, yet this does not imply that $L$ was a direct descendent of $P$, since there are noticeable differences between them.

Let us first look at the following passages:

\section{$P$}

Sinu moi Anadane da budêta oči tvoi doli zrêći a glas tvoi vele potulen. Zač' ako bi glasom' č(lovê)kb mogal' počtên'ê dobiti osal' bi rikaniem .b. hramini podvigal na sebi.

$$
\text { [p. 390] }
$$

$L$

Сину мои анадане да-будете очи твоие долие гледати а-глась твои веле потулень иере ако-би велициемь гласомь услишань био осао-би двигао риканомь на-себи три граде и-четири жупе даржао
D

Sinu moj da budita oči tvoje, doli gledeči glas tvoj velje potišan, jer ako bi kričem poštenje hotil dobiti osal bi Ruknenjem dvi hiži zdvignul na sebi

The saying in $P$ (»let thine eyes look on the ground and thy voice be soft; if it were a loud voice alone that decided the event, the ass could build two houses in a day with his braying «) is mostly identical with other Near Eastern as well as most of the Slavonic recensions. ${ }^{20}$ In $L$, however, the last part of this passage is altered so that instead of »two houses « occurs the phrase »the ass

${ }^{20} R I$ Сыну, очи твои да будета долу зряща, глас твой обниженъ; аще бо и великымъ гласомъ храминъ ся создати, оселъ бы риканиемь своимь 2 храмънъ въздвиглъ единым днемь [р. 30]; Sav29 аще се бы храмь гласомь сьзидиль то осель би риканимь .в. храма съзидаль вь юнь днь. [р. 499] 
could build three towns, and rule four župas«. This might look like a simple rewriting by the scribe of $L$; however, as will be shown later, this expression appears in some South Slavonic copies composed outside Croatia.

The divergence between $P$ and $L$ is also found in the forged letter of Anadan addressed to the King of Persia. In other recensions, for example, in $R I$ and $S 309$, this part reads as follows:

$R I$ написа // грамотъ 2. К ратному цареви перскому, емуже имя Алонъ, и тако написа [pp. 38//40]

'(Anadan) wrote a letter to the King of Persia, whose name was Allon.'

S309 и написа двъ книљъ, .а. црю перскому емуже име / Алонь и тако написавь рекь $[13 \mathrm{r} / \mathrm{v}]$

'and he wrote two letters, one to the King of Persia whose name was Allon, and ...'

Let us look at the corresponding part in the Croatian copies:

$P$ I napisa Anadan' dva lista i da edan c(êsa)ru i r(e)če c(êsa)re [p. 393]

'Then Anadan wrote two letters, and gave one to the Tsar and said to him,'

$L$ и-потомь анакань (sic) написавь двие книзи иедну посла алону цару [34r/p. 50]

'Then Anadan wrote two letters, and sent one to Allon, the Tsar.'

$D$ I napisa Anadam dva lista i da jednoga kralju Sinagripu [73v/p. 37]

'Then Anadan wrote two letters, and gave one to King Sinagrip'

As is evident, $P$ lacks the proper name Allon, whereas $L$ contains it. It would be hardly conceivable that the scribe of $L$ could write the name Allon if he were relying only on $P$ or $P$ 's direct descendent that might have lacked the name. In this respect $»$ Kralju Sinagripu« in $D$ is also interesting, as it could indicate that by his own decision Derečkaj filled the lacuna of the source text in which the King's name was not mentioned, as was the case of $P$.

Based on these differences, accordingly, we can conclude that $L$ is not a direct descendent of $P$, but rather that they had a common source from which two variants were derived.

\section{COMPARISON WITH OTHER SOUTH SLAVONIC COPIES}

The observations in the previous section reveal that the Croatian copies are derived from the same source and thus form one recension (furthermore, the Croatian recension), but that $\mathrm{L}$ is not directly connected to $P$. In this section we will examine how the Croatian recension is related to other Slavonic copies.

The first point we need to draw our attention to is that the lack of an episode concerning Anadan, as mentioned in 3.2.2. (I), is a feature shared also 
by $C h$ and $B 53$. This fact leads us to assume that the episode in question was dropped at some stage of transmission of SAW from the older South Slavonic recension represented by $\operatorname{Sav} 29$ to a younger recension, and that the younger recension served as the source for $C h, R s 53$, and the Croatian recension.

The next point to note is that the quotation of $»$ the fear of the Lord is the beginning of wisdom ...«, occurring in the Croatian recension (see 3.2.2. (II)), is also found in $B 53$.

B53 Сّну мои анิаане начело премудрости стрӑ̀ гн ё. и разумь

блг̆ль творещимь е. Сн̆у мои анане аще хощеши бити премударь буди мльчеливь и ... [46v]

'Oh my son, the beginning of wisdom is the fear of the Lord, to whoever performs this teaching the Lord will bless ...'

This sentence is identical to the Slavonic translation of Psalm 110:10. The corresponding verse in the Psalterium Sinaiticum (PS) and the Pogodin Psalterium $(P P)$ prove this:

$P S$ поконь прђмждрости страхъ гйь:) Разоумъ же благъ вьсьмь творнаштимъ њ

[SEVER'JANOV 1922: 147]

PP НачАло прђмждрости страхъ Г̈нъ. Разоум’ же бл̈гь всЂмъ творАщнимь нА

[JAGIĆ 1907: 552]

Accordingly, the conformity of the sentence in B53 to Psalm 110:10 for one thing, and the concord of the first part of the phrase »начело премудрости ...« in $B 53$ and the corresponding expression in the Croatian recension for another, allow us to conclude that the phrase »the beginning of wisdom is ...« in the Croatian recension is also a modified version of Psalm 110:10. Thus, the development of this part can be assumed as follows: In the course of transmission of SAW a quotation of Psalm 110:10 was interpolated into the very beginning of the part of sayings and a new variant was created. While this pattern was transmitted down to $B 53$ mostly unchanged, another variant appeared in which the second part of the same verse was omitted; furthermore, in this latter variant, the adjective meaning »first « was added to the noun »the beginning « so that the phrase »the first beginning « pervo načelo was created, as is witnessed in $P$. Based on this pervo načelo, the local vernacular forms of parvo počelo and prvi početak in $L$ and $D$, respectively, were created.

As a third point, we would like to remark on the passage of »utla ladia « (a ship with a hole) noted in 3.2.2. (III), since this phrase is also found in B53, as shown below:

B53 Сн̈у мои ан̆ане боле ти се ю возити у оутле лад̆е на мутне водии нежели зле жене съветь казати ере ће оутла ладиа едну погубити а зла жена мн̆угу ће жизань расточитии. [49r/v] 
The fourth point of importance is the date in Anadan's false letter, observed in our 3.2.2.(IV). In respect of this point, curious differences are found among some of the South Slavonic copies. In S309 the date reads »August 15 th «, which concords with $L$, whereas the place name appears as »the Egyptian field « in accordance with other older recensions. In B53, in contrast, the part in question perfectly concords with $L$ :

S309 пріиди на поле егӱпьгское мц́а авгу .ё. дн̆ь. [13v]

$B 53$ да будете на полю шдорскимь .ёі. д̈нь. мцца марта [52v]

$B 828$ shows confusion: in one letter addressed from the name of King Sinagrip to Akir, we find »... рече Анадань мсця авгоуста« (said Anadan in the month of August) ${ }^{21}$ whereas in the other letter forged under the name of Akir addressed to »King of Egypt«, the sentence reads: »прїди на полю єгыптьскою мца мар $\theta \epsilon . \epsilon i$. дн̈ь. (the Month of March the 15th).

To summarize, the change of »August « to »March « is reflected not only in the Croatian recension but also in $B 53$, while the rewriting of the date $" 25$ th as »15th «, witnessed in $L$, is also observed in $B 53, S 309$, and $B 828$. The process by which the date »the 6th « appeared in $P$ and $D$ was already observed in the previous section. Regarding the place name, evidence is less variable: »the field of Odor « opposed to the old form of »the Egyptian field « is found only in the Croatian recension and B53. ${ }^{22}$

As a last point we would like to note the expression "three towns, four župas « found in $L$. This interesting alteration is, as we have remarked earlier, in fact not a creation of $L$ 's scribe, since the same phrase is found in B53:

$B 53$ шсьл би риканиемь на себе / дићи .г. граิе и .д̆. жупе дрьжал би $[47 \mathrm{v} / 48 \mathrm{r}]$

And curiously, S309 also contains the same expression:

S309 аще бы повеле гласїю дъло велико 〈...> wсель бы риканїемъ двигль двђ храмине и трї градове и четири жоупъ [6/6v]

\section{INTERRELATION OF THE SOUTH SLAVIC COPIES}

Our observations in the previous sections reveal that the Croatian recension concords with B53 in respect of (1) the lack of the episode concerning Anadan at the beginning of the third part, (2) the quotation of Psalm 110:10 »the fear of the Lord is the beginning of wisdom «, (3) the inclusion of a meta-

\footnotetext{
${ }^{21}$ It is not possible to read the day.

${ }^{22}$ Ch готовь боуди мца, аүста. к̆є. дн̈ь. на поле єгӱпьтско.
} 
phorical saying referring to »a ship with a hole«, and (4) the date and the place in the false letter from Anadan. Regarding the passage in (5), »three towns and four župas«, $L$ differs from $P / D$ and concords with B53 and $S 309$. The table below summarizes all these.

\begin{tabular}{|c|c|c|c|c|c|c|c|c|c|}
\hline & \multicolumn{3}{|c|}{ Slavia Latina } & \multicolumn{6}{|c|}{ Slavia Orthodoxa } \\
\hline & \multicolumn{6}{|c|}{ Croatian/Bosnian/Serbian regions } & \multirow{2}{*}{\multicolumn{2}{|c|}{$\begin{array}{c}\text { Bulgaria } \\
\text { Bulgarian }\end{array}$}} & \multirow{2}{*}{$\begin{array}{c}\text { Russia } \\
\text { RI }\end{array}$} \\
\hline & \multicolumn{3}{|c|}{ Croatian recension } & \multicolumn{3}{|c|}{ Serbian MSs } & & & \\
\hline & $\mathrm{P}$ & $\mathrm{D}$ & $\mathrm{L}$ & B53 & S309 & B828 & Sav29 & $\mathrm{Ch}$ & \\
\hline (1) & \multicolumn{4}{|c|}{ N.I. } & \multicolumn{3}{|c|}{ I. } & N.I. & I. \\
\hline (2) & ○ & $\circ$ & ० & o & $x$ & $x$ & $x$ & $x$ & $x$ \\
\hline (3) & o & $\circ$ & o & o & $x$ & $x$ & $x$ & $x$ & $x$ \\
\hline \multirow{2}{*}{ (4) } & M. 6 & M. 6 & M. 15 & M. 15 & A. 15 & A./M. 15 & A. 25 & A. 25 & A. 25 \\
\hline & \multicolumn{4}{|c|}{$»$ Odorski« } & \multicolumn{5}{|c|}{$»$ Egypatski« } \\
\hline (5) & $x$ & $x$ & o & o & $\circ$ & $x$ & $x$ & $x$ & $x$ \\
\hline
\end{tabular}

Fig. 1. SAW in South Slavonic copies*

S1. 1. Priča o premudrom Akiru u južnoslavenskim prijepisima

* Remarks on the table: N.I. in (1) means the episode in question is not included, I. means included; the mark $\circ$ in (2) (3) and (5) stands for the inclusion of the corresponding phrases; $\mathrm{M}$. in (4) means »March« and A. $-»$ August $\ll$.

The same relationship can be laid out in the stemma below.

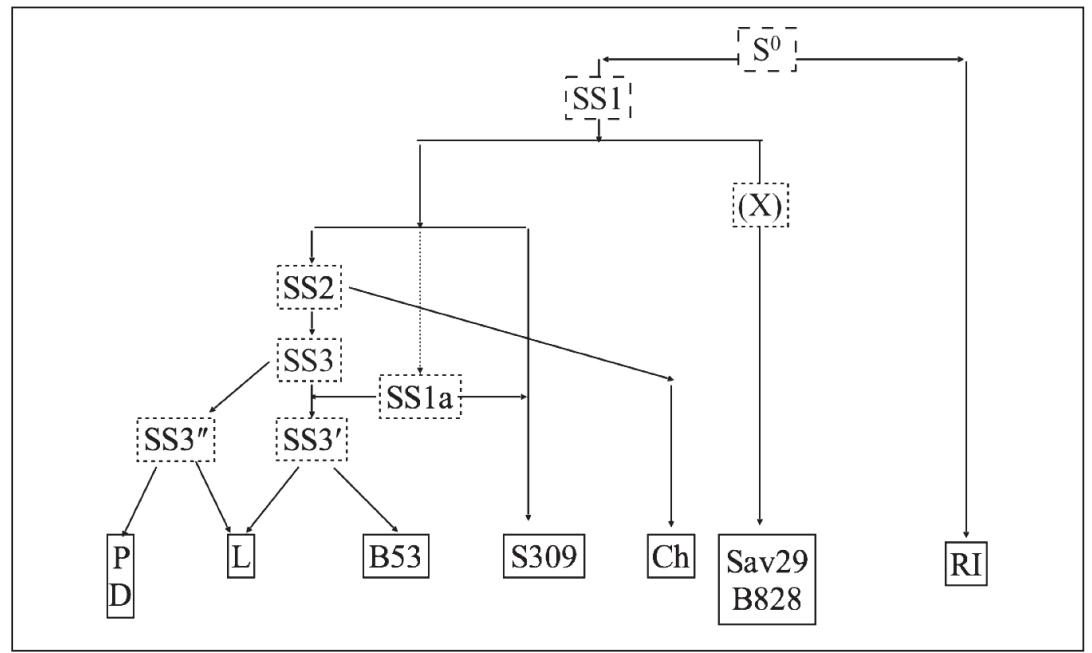

Fig. 2. The transmission pattern of South Slavonic SAW

S1. 2. Stemma codicum južnoslavenskih prijepisa Priče o premudrom Akiru 
Thus, our assumption is that first, from the Slavonic archetype $\left(\mathrm{S}^{0}\right)$ the first South Slavonic recension SS1 was created, which is reflected in Sav29 as well as $B 828$. SS1 also served as a source for the younger recensions, one-SS2, in which the episode of Akir and Anadan that should have been narrated at the beginning of the third part was omitted, and another - SS1a, a variant of $\mathrm{S} 1$, that instead of the older element »two houses « included the phrase »three towns and four župas « (SS1a). While from SS2 appeared the archetype for the Croatian recension and $B 53$, namely $\mathrm{SS} 3, \mathrm{SS} 1$ a somehow reached the scribe of $S 309$ on one hand, and was reflected in some copy belonging to SS3 on the other. The newly composed recension SS3' was further transmitted to create $L$ and B53. SS3 without the influence of SS1a descended to SS3" to be the source for $P$ and $L$. Considering the mixed features of $L$ we need to consider that the scribe of $L$ or whoever had engaged in transmitting SAW to $L$ could have used both SS3' and SS3".

\section{CONCLUSION}

As we have observed in this paper, the South Slavonic tradition of SAW is characterized by textual diversity. This is partly because of the non-canonical nature of SAW, and partly because of the story's compositional structure; in any case, intentional participation by the scribes is evident. The attempt to rewrite source texts is observed elsewhere; particularly conspicuous is the lexical replacement of older items with newer items that were more usual for the scribes and the communities to which they belonged. We can also observe some words appearing in response to the social as well as linguistic environments wherein the scribes composed their »editions«. A clear example reflecting such environments is the word ґнчарь (янычар < Turkic yeniçeri). This word, witnessed only in $P$ and $L$ (i.e., SS3" in our stemma), is an indication that Turkic influence was already appearing in language practice, and, we may suppose, the fear of Ottoman expansion was perceptible in the society to which the scribes of this recension belonged.

To conclude, various degrees and natures of textual differences in the South Slavonic recensions, the Croatian among others, are at least in part the outcome of scribes' intentions to make the source text conform to the environment in which their activities were performed.

It is noticeable, finally, that despite the religious border dividing the South Slavic regions into Slavia Orthodoxa and Slavia Latina, SAW was transmitted from the East to the West across this border. This suggests that in this region there existed a cultural network of sorts in which scribes and those who worked on the transmission of various pieces of textual knowledge were 
somehow interconnected. How such a network was formed and what consequences can be found in the South Slavic region besides our SAW are questions that need to be addressed in another endeavor.

\section{REFERENCES}

BADURINA STIPČEVIĆ, V. 2013. Priča o premudrom Akiru. Hrvatska srednjovjekovna proza, I. Zagreb: Matica hrvatska, 251-260.

BADURINA STIPČEVIĆ, V. 2015. Priča o premudrom Akiru u hrvatskoglagoljskom Petrisovu zborniku (1468). Hrvatsko glagoljaštvo u europskom okružju. Zagreb: Staroslavenski institut, 379-398.

BRATULIĆ, J; S. DAMJANOVIĆ. 2005. Hrvatska pisana kultura: izbor djela pisanih latinicom, glagoljicom i ćirilicom od VIII. do XXI. stoljeća 1 1. Križevci: Veda.

BROSSET, M. 1832. Extrait du manuscrit arménien $\mathrm{n}^{\circ} 114$ de la Bibliotèque royale, relatif au calendrier géorgien. Nouveau Journal Asiatique, ou recueil de mémoires, d'extraits et de notices relatifs aux études orientales 10: 526-532.

CONYBEARE, F.; J. R. HARRIS; A. S. LEWIS. 1898. The Story of Ahikar, from the Syriac, Arabic, Armenian, Ethiopic, Greek and Slavonic versions. London: C. J. Clay and sons.

COWLEY, A. E. 1923. Aramaic Papyri of the Fifth Century B.C. Oxford: Clarendon Press.

ČDL = HRASTE, M.; P. ŠIMUNOVIĆ; R. OLESCH. 1979. Čakavisch-deutsches Lexikon, I. Köln: Böhlau.

GHNR = FINKA, B.; R. KATIČIĆ (gl. ur.). 1991. Gradišćanskohrvatsko-hrvatsko-nimški rječnik. Zagreb - Eisenstadt.

HERCIGONJA, E. 1983. Nad iskonom hrvatske knjige. Rasprave o hrvatskoglagoljskom srednjovjekovlju. Zagreb: SNL.

HERCIGONJA, E. 2002. Priča o premudrom Akiru (Historia de sapientissimo Achiore), Hrvatska književna baština 1. Zagreb: Exlibris, 11-54.

JAGIĆ, V. 1867. Historija književnosti naroda hrvatskoga i srbskoga. Zagreb: Albrecht.

JAGIĆ, V. 1868. Prilozi k historiji književnosti naroda hrvatskoga i srbskoga. Arkiv za povjestnicu jugoslavensku IX: 65-151.

JAGIĆ, V. 1892. Der weise Akyrios. Byzantinische Zeitschrift 1/1: 107-126.

JAGIĆ, V. 1907. Словъньска псалътірь. Psalterium Bononiense. Vienna: Gerold.

KOPEČNÝ, F. 1981. Základni všeslovanská slovni zásoba. Praha: Akademia.

LINDENBERGER, J. 1983. The Aramaic proverbs of Ahiqar. Baltimore: Johns Hopkins University Press.

LITTMAN, R. J. 2008. Tobit. The Book of Tobit in Codex Sinaiticus. Leiden: Brill.

LOURIÉ, B. 2013. The Syriac Ahiqar, Its Slavonic Version, and the Relics of the Three Youths in Babylon. Slověne 2/2: 64-117.

MARZOLPH, U.; R. VAN LEEUWEN; H. WASSOUF (eds.). 2004. The Arabian Nights Encyclopedia. Santa Barbara (CA): ABC Clio. 
NAU, F. 1909. Histoire et sagesse d'Ahikar l'Assyrien (fils d'Anael, Neveu de Tobie): traduction des versions syriaques avec les principales différences des versions arabes, arménienne, grecque, neo-syriaque, slave et roumaine. Paris: Letouzey et Ané Éditeurs.

SMITH, P. 1903. A Compendius Syriac Dictionary : Founded upon the Thesaurus Syriacus of R. Payne Smith (edited by J. Smith). Oxford: Clarendon Press.

SYRKU, P. 1884. Zur mittelalterlichen Erzälungsliteratur aus dem Bulgarischen. Archiv für slavische Philologie 7: 78-98.

ŠTEFANIĆ, V. 1960. Glagoljski rukopisi otoka Krka. Zagreb: JAZU.

ŠTEFANIĆ, V. 1969. Hrvatska književnost srednjega vijeka. [Pet stoljeća hrvatske književnosti, knj. 1.] Zagreb: Matica hrvatska.

WEIGL, M. 2010. Die aramäischen Achikar-Sprüche aus Elephantine und die alttestamentliche Weisheitsliteratur. Berlin: De Gruyter.

БАРСОВ, Е. В. 1886. Акир премудрый во вновь открытом сербском списке XVI в. Чт. ОИДР 3/2: 1-11.

БЕЛОБРОВА, О. О.; О. В. ТВОРОГОВ. 1970. Переводная белетристика 11-13 вв. Я. С. Лурье (отв. ред.). Истоки русской беллетристики: Возникновение жанров сюжетного повествования в древнерусской литературе. Ленинград: Наука, 142-194.

БОБРОВ, А. 2014. Происхождение и судьба Мусин-Пушкинского сборника со »словом о полку игореве«. Труды Отдела Древнерусской Литературы, т. 64, $528-553$.

БОГДАНОВИЧ, Д.; А. МИЛТЕНОВА. 1987. Апокрифният сборник от манастира Савина XIV в. в сравнение с други подобни южнославянски ръкописи. Археографски прилози 9: 7-30.

ВОЛКОВА, Т. 2011. Повесть об Акире премудром в печорской рукописной традиции. Известия Уральского государственного университета, сер 2, гуманитарнье науки, но. 2 (90): 113-128.

ГЛАДКОВА, О. В. 2008. Повесть об Акире Премудром. А. С. Демин (отв. ред.). История древнерусской литературы: Аналитическое пособие. Москва: Языки славянских культур, 613-620.

ГРИГОРЬЕВ, А. Д. 1913. Повесть об Акире Премудром. Исследование и тексты. Москва: Синодальная Типография.

ДУРНОВО, Н. 1915. Материалы и исследования по старинной литературе. 1. К истории Повести об Акире. Москва: Синод. тип.

ДУРНОВО, Н. 1931. Дубровницкий список повести об Акире. Zbornik iz Dubrovačke prošlošti Milanu Rešetaru o 70oj godišnjici života. Dubrovnik: Jadran, 221-226.

ИВАНОВ, Й. 1935. Старобългарски разкази. Текстове, новобългарски превод и бележки. София, 245-249.

ЙОНОВА, М. 1987. Разпространение и развитие на повестта за Акир Премъдри в средновековните литератури на южните и източните славяни. Paleobulgarica/ Старобългаристика XII/1: 104-109. 
ЈОВАНОВИЋ, Т. 2012. Хрестоматија средњовековне књижевности. Т. 1. Старословенска и преводна књижевност. Београд: Филолошки факултет, 314-329.

КАРАМЗИН, Н. 1818. История государства росийскаго, т. 3. Петербург.

КУЗИДОВА, И. 2010. Преписът на Повестта за Акир Премъдри в ръкопис № 29 от манастира Савина (около 1380 г.). М. Йовчева (отг. ред.). Пъние мало Гешргию. Сборник в чест на 65-годишнината на проф. дфн Георги Попов. София: Издателски център »Боян Пенев«, 492-509.

КУЗИДОВА, И. 2012. Textologische Übersicht von südslawischen Abschriften der Geschichte über Akiris den Weisen. Кирило-Методиевски студии 21: 309-320.

МИХЕЛЬСОН, М. Н. 1912. Русская мысль и речь. Свое и чужое. Опьт русской фразеологии. Санкт-Петербург: Типография Акционерного Общества »БрокгаузЕфрон «.

ПЕРЕТЦ, В. И. 1916. К истории текста »Повести об Акире Премудром«. ИОРЯС XXI/1: 262-278.

ПИОТРОВСКАЯ, Е. К. 1976. Усть-цилемская обработка Повести об Акире Премудром. Труды Отдела Древнерусской Литературы 31: 378-383.

ПИОТРОВСКАЯ, Е. К. 1978. О ІІІ русской редакции Повести об Акире Премудром. Вспомогательные исторические дисииллины 10: 323-327.

ПОЛЕВОЙ, Н. 1825. Древний русский перевод арабской сказки. Московский телеграф 3/11: 227-235.

ПОЛЕВОЙ, Н. 1842. Древнерусские повести. Русский вестник 1: 54-65.

ПЫПИН, А. Н. 1855. Очерки изь старинной русской литературы. Сказка изъ Тысячи и Одной Ночи въ русскомъ переводъ въ XIII-XIV в. Отеч. заn. 2: 109-150.

РАДЕНКОВИЋ, Л. 2009. Укрытие стариков как элемент обряда перехода (на материале преданий об убиении стариков). И. А. Седакова (отв. ред.). Переходы. Перемены. Превращения. Балканские чтения 10. Тезисы и материалы. 31 марта - 2 апреля 2009 года. Москва: Институт славяноведения РАН, 107-114.

РЕШЕТАР, М. 1926. Наукь примудрога Акира. Либро од мнозиех разлога: Дубровачки ћирилски зборник од г. 1520. Сремски Карловци, 48-55.

СЕВЕРЬЯНОВ, С. 1922. Синайская псалтырь. Глаголическій памятникъ ХІ 8. Петроград.

СТАНКОВИЋ, Р. 1980. Слово Акира премудрог (препис из 1570/80. године). Археографски прилози 2: 219-227.

ТВОРОГОВ, О. В. 1969. „Сокол трех мытей« в повести об Акире премудром. Н. А. Мещерский (отв. ред.). Вопросы теории и истории языка: сборник статей посвященный памяти Б. А. Ларина. Ленинград: Изд-во Ленинградского университета, 111-114.

ТВОРОГОВ, О. В. 2004. Повесть об Акире Премудром. Библиотека литературь Древней Руси, m. 3. Санкт-Петербург: Наука, 28-57.

ЭССЯ = ТРУБАЧЕВ, О. Н. (ред.). 1974. Этимологический словарь славянских языков: Праславянский лексический фонд. Москва: РАН. 


\section{Sažetak}

\section{Keiko Mitani \\ HRVATSKA TRADICIJA PRIČE O AKIRU PREMUDROM U JUŽNOSLAVENSKIM PRIJEPISIMA}

Priča o Akiru premudrom, apokrifna priča koja potječe s antičkoga Bliskog istoka iz vremena prije 500. g. pr. Kr., prevedena je na crkvenoslavenski jezik najvjerojatnije u 12. ili 13. stoljeću. Priča je bila raširena pretežno među pravoslavnim Slavenima, većinom u Rusiji, no ipak je prispjela i do Hrvatske, u Dalmaciju. Najstariji prijepis sačuvan je na Balkanu, što sugerira da je prvi prijevod nastao na južnoslavenskom području, premda konačno rješenje pitanja o nastanku slavenskoga prijevoda još i danas ostaje otvoreno, zbog nepostojanja grčke verzije. U Hrvatskoj je priča poznata po trima prijepisima, napisanim na glagoljskom, ćiriličnom i latiničnom pismu.

U radu se predstavlja tekstualni odnos južnoslavenskih prijepisa Priče, nastalih između 14. i 17. stoljeća, te se iznosi dosada neprimijećena povezanost triju hrvatskih prijepisa s dvama rukopisima očuvanima u Srbiji i Bugarskoj. Na temelju analiza jezičnih i sadržajnih značajka južnoslavenskih prijepisa Priče prikazuje se postanak različitih redakcija hrvatskih i drugih južnoslavenskih prijepisa. Ističe se kakva je pri tome bila uloga prepisivača, koji nisu samo prepisali, nego su preradili prethodni tekst u skladu s jezičnom praksom i društvenim uvjetima u kojima su djelovali.

Ključne riječi: Priča o Akiru premudrom, slavenski apokrifi, srednjovjekovna hrvatska glagoljska pismenost, Slavia Latina i Slavia Orthodoxa 